\title{
An Assessement of Paddy Production System in Central Kenya with Special Reference to Micronutrients
}

\author{
Caroline A. Kundu ${ }^{1,2}$, Masaya Ishii ${ }^{1}$, Kuniaki Sato ${ }^{1}$, Raphael K. Wanjogu ${ }^{3}$, Daigo Makihara ${ }^{4}$, Akira Yamauchi ${ }^{5}$ \\ $\&$ Tsugiyuki Masunaga ${ }^{1}$ \\ ${ }^{1}$ Faculty of Life and Environmental Science, Shimane Univerity, Japan \\ ${ }^{2}$ Kenya Agricultural and Livestock Research Organization (KALRO), Kenya \\ ${ }^{3}$ Mwea Irrigation Agricultural Development Centre (MIAD), Kenya \\ ${ }^{4}$ International Co-operation Center for Agricultural Education (ICCAE), Nagoya University, Japan \\ ${ }^{5}$ Graduate School of Bioagricultural Sciences, Nagoya University, Japan \\ Correspondence: Tsugiyuki Masunaga, Faculty of Life and Environmental Science, Shimane University, Japan. \\ Tel/Fax: 81-(0)852-326-066. E-mail: masunaga@life.shimane-u.ac.jp
}

Received: March 8, 2017

Accepted: April 20, $2017 \quad$ Online Published: May 15, 2017

doi:10.5539/jas.v9n6p49

URL: https://doi.org/10.5539/jas.v9n6p49

\begin{abstract}
Soil degradation reduces agricultural productivity and poses a great threat on food security status of households. In Kenya, farmers have for a long time been using only nitrogen and phosphorous based fertilizers oblivious of the soil fertility status. In most cases, there has been lack of plant response to these fertilizers, which could be due to a limitation of nutrients other than nitrogen and phosphorous. Soils are considered as variable natural bodies because of combined intrinsic and extrinsic factors of different intensities at a field or a larger region scale therefore an understanding of such variability is imperative to provide insights needed in their management. This study was thus initiated to assess the availability of soil micronutrients from rice growing Vertisols in the Mwea irrigation scheme. Top $(0-15 \mathrm{~cm})$ soil samples were collected across paddy fields in the irrigation scheme and analyzed for iron $(\mathrm{Fe})$, zinc $(\mathrm{Zn})$, copper $(\mathrm{Cu})$ and manganese $(\mathrm{Mn})$ by the $0.1 \mathrm{~N} \mathrm{HCl}$ extraction method. Soil $\mathrm{pH}$ (water and $1 \mathrm{M} \mathrm{KCl}$ ) was also measured using the glass electrode $\mathrm{pH}$ meter. Soil solution $\mathrm{pH}$ ranged from 4.56 to 8.05 and 3.33 to 6.63 for water and $1 \mathrm{M} \mathrm{KCl}$ respectively. Soil Fe, Zn, Cu and $\mathrm{Mn}$ concentration varied greatly and ranged from undetected to $1360.6,0.12$ to 8.00 , undetected to 9.29 and 1.50 to $849.2 \mathrm{mg} / \mathrm{kg}$ respectively. Coefficient of variations (CVs) for soil micronutrients ranged from $64 \%$ to $154 \%$ indicating very high variability. Soil $\mathrm{pH}$ was least variable with $\mathrm{CVs} 12 \%$ and $15 \%$ for water and $\mathrm{KCl}$ respectively. These results imply that the paddy soils in Mwea region are highly heterogeneous and soil micronutrients are enriched in some areas and depleted in others due to farm management practices and soil properties. Averagely, soil available $\mathrm{Zn}$ was deficient across the scheme and as such $\mathrm{Zn}$ fertilization can be effective in increasing soil $\mathrm{Zn}$ concentration and availability in the soil-root interface further enhancing soil productivity and yield quality. Attention should also be paid to appropriate farm management practices to avoid accumulation or depletion of nutrients.
\end{abstract}

Keywords: micronutrients, Mwea irrigation scheme, paddy soil, zinc deficiency, zinc fertilizer

\section{Introduction}

Soil plays a major role in determining the sustainable productivity of an agro-ecosystem. It is an important source of bioavailable micronutrients and a shortage or surplus of bioavailable micronutrients in the soil limits growth of crops (Liu et al., 2004; Ye et al., 2015). Out of the 16 plants nutrients, zinc ( $\mathrm{Zn})$, copper (Cu), iodine (I), manganese ( $\mathrm{Mn})$, molybdenum (Mo), boron (B), iron ( $\mathrm{Fe}$ ) are among those referred to as micronutrients. These elements are required in small quantities for plant growth but have agronomic importance as macronutrients playing a vital role in growth and development of plants (Zayed, Salem, \& Sharkawy, 2011; Cholarajan \& Vijayakumar, 2013). Furthermore, plant growth and development may be retarded if any of these elements is lacking in the soil or is inadequately balanced with other nutrients (Cholarajan \& Vijayakumar, 2013; Das, 2014).

Cropping systems and fertilization practices have been shown to influence the availability of soil micronutrients (Wei, Hao, Shao, \& Gale, 2006). Studies have shown that soil $\mathrm{pH}$, phosphorus and organic matter contents 
influence the availability of micronutrients under various soil conditions (Wei et al., 2006; Li et al., 2007). According to Rieuwerts, Ashmore, Farago, and Thomton (2006) and Zhao, Liu, Xua, and Selim (2010), pH is the most important predictor for the estimation of extractable heavy metals from soil because of its strong effects on speciation, solubility and their bioavailability in soil solution. The capacity of a soil to supply microelements directly influences plant structural development and physiological function, regulates plant growth and development and product quality (Ye et al., 2015).

In Kenya, rice is a major cereal food crop ranking third after maize and wheat. In the recent years, its importance has grown as per capita consumption, particularly in urban areas, has increased far more rapidly than for other cereal crops (Ministry of Agriculture [MoA], 2009; European Cooperative for Rural Development [EUCORD], 2012). According to the EUCORD (2012) report, statistics showed that annual rice consumption in Kenya had increased at a rate of $12 \%$ compared to wheat at $4 \%$ and maize at $1 \%$. Unfortunately, the country is not able to meet the soaring demand and is only able to produce a fifth of its national needs. The deficit is normally covered through imports mainly from Pakistan, Vietnam, Thailand and India (United States Agency International Development [USAID], 2014). Nonetheless, there are enormous possibilities for increasing rice productivity through better crop management, improved timeliness of operations and better market understanding considering the available vast unused productive potential (Rosemary, Bibiana, Njuguna, Dominic, \& Daniel, 2010).

Rice production in Kenya is mainly from irrigation schemes covering approximately 13,000 ha and includes irrigation schemes in Nyanza; West Kano and Ahero, Western; Bunyala scheme and Mwea irrigation scheme in Central (MoA, 2009). About 95\% of rice consumed in Kenya is produced from government managed irrigation schemes while the remaining 5\% is produced under rain-fed conditions (Muhunyu, 2012; USAID, 2014). The largest rice producing area is the Mwea irrigation scheme (MIS); where production is mostly based on the conventional practice of continuously flooding the paddy fields (MoA, 2009; Ndiiri, Mati, Home, \& Odongo, 2013). A study by Kondo, Toshinari, and Wanjogu (2001) in the MIS indicated that the soils are medium to high in terms of major essential elements except potassium. Further work by Kihoro, Njoroge, and Hunja (2013) concluded that Mwea soils are suitable for rice cultivation. Despite this great potential, there has been a marked stagnation in the mean crop production which has been attributed to soil chemical and physical degradation due to continuous mono-cropping, use of production techniques that are inefficient among many other factors as reported by Nyamai et al. (2012). Therefore, improving rice yields in existing irrigated areas rather than further expansion is more likely to be the main source of growth for the crop in Kenya only if proper soil and water management is taken into account especially during the vegetative phase of the crop (Nyamai et al., 2012). Sustainable productivity of a soil mainly depends on its ability to supply essential nutrients to growing plants; therefore an understanding of the differences and distribution patterns of soil bioavailable nutrients is vital in its management and fertilizer applications (Liu et al., 2004).

Although rice is an important cereal crop for Kenya's population, no information is available on its soil micronutrient nutritional status yet according to Bell and Dell (2008), micronutrient deficiency is reported as a major constraint to productivity, stability and sustainability of soils in many parts of the world. Micronutrient deficiencies in plants are common in calcareous soils with high $\mathrm{pH}$ such as those found in arid and semiarid regions (Alloway, 2008). Due to its special geographical positioning and importance, the MIS represents a critical entry point in ensuring that rice production is enhanced in the country. Therefore this study was initiated to quantify micronutrient ( $\mathrm{Fe}, \mathrm{Mn}, \mathrm{Cu}$ and $\mathrm{Zn}$ ) concentrations and their distribution in the surface soils of MIS. The key challenges and opportunities identified in Mwea could be used as a point of reference for enhancing rice production in other existing or potential rice production areas. In addition, our work aimed at identifying the possible hot spots for micronutrient deficiencies and toxicities and recommend appropriate management strategies to avert the accompanying negative effects. The findings will provide guidelines beneficial for soil management and strategic sustainable agriculture in terms of micronutrients.

\section{Materials and Methods}

\subsection{Description of the Study Site}

The MIS is located on the lower slopes of Mt. Kenya in Kirinyaga County in Central Kenya. It lies within latitudes $37^{\circ} 13^{\prime} \mathrm{E}$ and $37^{\circ} 30^{\prime} \mathrm{E}$ and longitudes $0^{\circ} 32^{\prime} \mathrm{S}$ and $0^{\circ} 46^{\prime} \mathrm{S}$ with a mean annual precipitation of about 950 $\mathrm{mm}$. The area experiences bimodal rainfall with the long rains falling between March and May and short rains between October and December (Kihoro et al., 2013). According to Kenya's agro-climatic zoning the scheme traverses three agro-climatic zones with maximum moisture availability ratios ranging from 0.65 for zone III towards the highland slopes to 0.50 for the vast area covered by zone IV and to 0.4 for the semi-arid zone V (Sombroek, Braun, \& van der Pouw, 1982). The area is generally hot and average temperatures range between 23 
and $25{ }^{\circ} \mathrm{C}$, with about $10{ }^{\circ} \mathrm{C}$ difference between the minimum temperatures in June/July and the maximum temperatures in October/March. The predominant soils of the rice-growing areas of Mwea are Vertisols characterized by imperfectly drained clays, very deep, dark grey to black, firm to very firm and prone to cracking (Sombroek et al., 1982). Kondo et al. (2001) also observed predominant presence of Vertisols in the scheme and surrounded by Alfisols at higher elevation. The most appropriate season for rice cultivation is from August to December, when temperatures are opportune for grain filling and with less risk of disease incidence; but is same period when flow of rivers are at their lowest straining on water availability for irrigation (Mukiama \& Mwangi, 1989). Rice crop production is also complicated by the staggered planting calendar implemented in the scheme (Ijumba, Mwangi, \& Beier, 1990) since available water is not enough to reach all farmers during the most opportune rice growing season.

Data from MoA (2009) indicate that the entire irrigation scheme covers an area about 12,282 ha of which about 9,000 ha has been developed for paddy production. MIS is the largest and oldest of the seven governments managed irrigation schemes in Kenya developed in 1953. It is divided into five sections/units at different elevations namely Tebere and Mwea covering 1400 and 1300 ha respectively and Thiba, Wamumu and Karaba covering 1200, 1200 and 1100 ha respectively (Njagi, 2012). There is an out-grower section covering about 2300 ha where irrigation infrastructure has not been developed. The farmers in the out-grower section use water drained from the main irrigation scheme (Njagi, 2012). Mwea and Tebere sections are the largest and oldest to be developed while Karaba, the smallest located at the end of the scheme was the last to be developed in 1973 (Kabutha \& Mutero, 2002). The irrigation scheme gets its waters from two rivers the Nyamindi and Thiba which have no storage facilities. The Nyamindi mainly serves the Tebere (T) unit, while the Thiba serves Mwea (M), Thiba $(\mathrm{H})$, Wamumu $(\mathrm{W})$ and Karaba $(\mathrm{K})$ units. The water is drawn from the rivers by gravity through dikes and distributed via unlined open channels to and out of the farms. Rice is grown as a mono-crop for one season in a year and uses the flooded-paddy irrigation method. Water resources from the Nyamindi that exceed the sum required for river maintenance flow and for irrigation inTebere section is regarded as surplus water which is transferred to the Thiba river in cases of shortage via a link canal (Kabutha \& Mutero, 2002; Abdullahi, Mizutani, Tanaka, Goto, \& Matsui, 2003).

\subsection{Soil Sampling and Analysis}

Soil samples were collected across the five production units of MIS namely Mwea, Wamumu, Karaba, Thiba and Tebere. Surface $(0-15 \mathrm{~cm})$ soil samples were collected in August 2013 and 2014 cropping period from Mwea rice fields. Benchmark sampling was applied where benchmark farms were identified and marked on MIS map generated from google. Several benchmark fields were identified across the five units for soil sampling and a total of 166 fields marked. Three to five representative soil samples were collected from fields averaging about 0.4 ha using a soil auger. The samples were mixed thoroughly and a composite sample from each field taken for evaluation. Transparent polythene bags were used to keep the samples and each labelled. The samples were dried, ground and passed through a $2 \mathrm{~mm}$ sieve in readiness for chemical analysis. The samples were exported to Japan and analysed in the Soil and Ecological Engineering laboratory, Faculty of Life and Environmental Science at Shimane University. The samples were analysed for $\mathrm{pH}$ and micronutrient ( $\mathrm{Fe}, \mathrm{Mn}, \mathrm{Cu}$ and $\mathrm{Zn}$ ) concentration.

Soil $\mathrm{pH}$ was measured potentiometrically using a glass electrode $\mathrm{pH}$ meter (HORIBA D-51) in 1:2.5 soil-water/1 $\mathrm{M} \mathrm{KCl}$ ratio suspension as described by the International Institute of Tropical Agriculture [IITA] (1979) and McLean (1982) using $8 \mathrm{~g}$ air-dried soil. Soil $\mathrm{Cu}, \mathrm{Fe}, \mathrm{Zn}$ and $\mathrm{Mn}$ concentrations were first extracted by mixing 2 $\mathrm{g}$ of air dried soil with $20 \mathrm{ml}$ of $0.1 \mathrm{~N} \mathrm{HCl}$ and shaking for 1 hour at 150 rounds per minute (rpm) as described by Osiname, Schulte, and Corey (1973). The solution was then filtered through ADVANTEC Whatman filter paper No. 6 and the micronutrient concentration in the leachate determined by Inductively Coupled Plasma-Atomic Emission Spectroscopy (ICPE-9000 Shimadzu Co. Ltd., Kyoto, Japan).

\subsection{Data Analysis}

Data were statistically analysed by ANOVA test using a statistical package, SPSS version 22 for windows (IBM SPSS). Descriptive statistics including mean, maximum, minimum and standard deviation were determined. Significant differences in mean soil parameter values were determined using Duncan's multiple range test $(\mathrm{p}<$ 0.05). The coefficient of variation (CV) which is the ratio of mean and standard deviation and expressed as a percentage for each soil parameter was also calculated. A Pearson correlation analysis was performed to determine the relationship between soil $\mathrm{pH}$ and soil micronutrient concentrations. Surface soil micronutrient concentrations in the MIS were evaluated basing on the micronutrient concentrations obtained from the laboratory analyses and were compared with established critical levels for optimum rice production. The CV was used to judge the scale of heterogeneity in surface soil $\mathrm{pH}$ and micronutrient status in the scheme. 


\section{Results and Discussions}

\subsection{Soil $p H$}

Table 1 shows the mean soil $\mathrm{pH}$ for MIS units.

Table 1. Soil $\mathrm{pH}($ mean $\pm \mathrm{SD})$ across the units

\begin{tabular}{lll}
\hline Unit name & $\mathrm{pH}_{\text {water }}$ & $\mathrm{pH}_{\mathrm{KCl}}$ \\
\hline Mwea & $5.99 \pm 0.75^{\mathrm{b}}$ & $4.52 \pm 0.71^{\mathrm{c}}$ \\
Thiba & $6.11 \pm 0.68^{\mathrm{ab}}$ & $4.68 \pm 0.60^{\mathrm{bc}}$ \\
Tebere & $6.51 \pm 0.81^{\mathrm{ab}}$ & $5.24 \pm 0.77^{\mathrm{ab}}$ \\
Wamumu & $6.28 \pm 0.78^{\mathrm{ab}}$ & $4.95 \pm 0.77^{\mathrm{abc}}$ \\
Karaba & $6.65 \pm 0.57^{\mathrm{a}}$ & $5.27 \pm 0.55^{\mathrm{a}}$ \\
\hline Overall mean & $6.27 \pm 0.76^{\circ}$ & $4.88 \pm 0.75$ \\
CV $(\%)$ & 12 & 15 \\
\hline
\end{tabular}

Note. Means followed by the same superscript letter within a column are not significantly different at $\mathrm{p}<0.05$;

SD: standard deviation, CV: coefficient of variation.

Across the irrigation scheme, surface soil solution $\mathrm{pH}$ ranged from 4.56 to 8.05 and 3.33 to 6.63 with mean values of 6.27 and 4.88 for $\mathrm{pH}$ water and $\mathrm{KCl}$ respectively. In our sampling, we observed soil colour variations where higher elevation unit fields especially in the Mwea unit contained reddish/brown characteristics that darkened out progressively in the lower elevation units.

Unit-wise, Mwea unit located at a slightly higher elevation had soil solution $\mathrm{pH}_{\text {water }}$ ranging from a minimum of 4.56 to a maximum of 8.05. In Thiba unit, the values ranged from 4.90 to 6.96 whereas in Tebere they ranged from 4.90 to 7.74. Further down in Wamumu and Karaba, the values ranged from 4.91 to 7.86 and 5.53 to 7.99 respectively. For $\mathrm{pH}_{\mathrm{KCl}}$ the values ranged from 3.33 to 6.62 in Mwea unit, 3.53 to 5.48 in Thiba and from 3.85 to 6.56 in Tebere unit. In the lower elevation units of Wamumu and Karaba, the values varied from 3.65 to 6.63 and 4.36 to 6.62 respectively. We noticed that surface soil $\mathrm{pH}$ gradually increased from the high elevation areas of Mwea towards the low topographical fields in Karaba. Surface soil solution $\mathrm{pH}$ values measured in water were consistently higher relative to $\mathrm{pH}$ values in salt solution $(\mathrm{KCl})$, an indication that Mwea irrigation scheme soils have a negative charge. The Kenya Soil Survey [KSS] (1987) rating (Table 2) was used to classify soil solution reaction.

Table 2. Key to soil solution reaction by KSS

\begin{tabular}{lll}
\hline Measured $\mathrm{pH}$ & Class description & Level of $\mathrm{pH}$ \\
\hline$<4.5$ & Extremely acid & Very low \\
$4.5-5.0$ & Very strongly acid & Low \\
$5.1-5.5$ & Strongly acid & Low \\
$5.6-6.0$ & Medium acid & Medium \\
$6.1-6.5$ & Slightly acid & Medium \\
$6.6-7.3$ & Neutral & Medium \\
$7.4-8.4$ & Mildly alkaline & High \\
$8.5-9.0$ & Strongly alkaline & High \\
$>9.0$ & Very strongly alkaline & Very high \\
\hline
\end{tabular}

Generally, the MIS soils can be classified as being slightly acidid with medium level pH. At unit level, Mwea unit soil reaction can be classified as being medium acidic, Thiba, Tebere and Wamumu units as slightly acidic while Karaba unit soils fall in the neutral description according to KSS (1987) key in Table 2. The moderately high soil solution $\mathrm{pH}$ had also been recorded by Kondo et al. (2001) who attributed it to the high carbonate concentration in the soils of this semi-arid region. In their study, they noted that the MIS soils which are mainly Vertisols were developed from calcareous-basalt parent material. The occurance of high soil $\mathrm{pH}$ has been associated with climate and/or parent material with drier conditions coupled with calcareous parent material favouring high soil $\mathrm{pH}$ (Kawaguchi \& Kyuma, 1974). In assessing the distribution, characteristics and 
classification of Vertisols; Murthy, Bhattacharjee, Landey, and Pofali (1982) also related soil pH to the nature of the parent material, climate and topographic situations adding that elements of climate and topography remaining the same, Vertisols are known to develop from parent materials rich in alkaline earths thus higher $\mathrm{pH}$ values. The gradual increase in soil solution $\mathrm{pH}$ with decreasing elevation can be attributed to increase in water soluble bases in the receiving depression unit of Karaba transported in irrigation water. In assessing the effects of landscape attributes and plant community types on soil chemical properties in a semiarid area in Iran, Rezaei and Gilkes (2004) reported a negative relationship between $\mathrm{pH}$ and altitude noting that with increased altitude comes increased leaching that reduces soluble bases and resulting in higher hydrogen ion $\left(\mathrm{H}^{+}\right)$activity that is registered as low $\mathrm{pH}$ level.

Descriptive statistics for soil solution $\mathrm{pH}$ gave $\mathrm{CVs}$ values of $12 \%$ and $15 \%$ for water and $\mathrm{KCl}$ respectively an indication that very low variability exists in soil $\mathrm{pH}$. Similar low variance in soil solution $\mathrm{pH}$ has been reported elsewhere for instance Aimrun, Amin, Ahmad, Hanafi, and Chan (2007) in Malaysia (2.6\%); Abu and Malgwi (2011) in Nigeria (10.3\%) and Addis, Klik, and Strohmeier (2015) in Ethiopia (6.5\%). This is because pH values are indicated on log scale of proton concentration in soil solution; otherwise there would be a much higher variability if soil acidity is expressed in terms of proton concentration directly (Sun, Zhou, \& Zhao, 2003). Given the results from the low CV statistics, we can construe that the soils in the study site are relatively homogenous in view of their $\mathrm{pH}$ status and this could be attributed to the homogeneous calcareous parent material and the drier climate in the area.

\subsection{Soil Micronutrient Concentration}

Mean soil concentrations for $0.1 \mathrm{~N} \mathrm{HCl}$-extractable $\mathrm{Cu}, \mathrm{Fe}, \mathrm{Mn}$ and $\mathrm{Zn}$ across the units is shown in Table 3 .

Table 3. Soil micronutrient concentration (mean \pm SD) across the units

\begin{tabular}{lllll}
\hline & \multicolumn{4}{l}{ Soil micronutrient concentration $(\mathrm{mg} / \mathrm{kg})$} \\
\cline { 2 - 5 } & $\mathrm{Fe}$ & $\mathrm{Mn}$ & $\mathrm{Cu}$ & $\mathrm{Zn}$ \\
\hline Mwea & $205.0 \pm 286.7^{\mathrm{a}}$ & $191.0 \pm 167.6^{\mathrm{ab}}$ & $1.69 \pm 1.06^{\mathrm{b}}$ & $1.47 \pm 1.22^{\mathrm{a}}$ \\
Thiba & $172.5 \pm 236.8^{\mathrm{a}}$ & $242.6 \pm 125.2^{\mathrm{a}}$ & $2.33 \pm 099^{\mathrm{b}}$ & $0.88 \pm 0.96^{\mathrm{a}}$ \\
Tebere & $102.7 \pm 91.5^{\mathrm{a}}$ & $114.9 \pm 83.3^{\mathrm{b}}$ & $2.21 \pm 1.37^{\mathrm{b}}$ & $1.09 \pm 0.67^{\mathrm{a}}$ \\
Wamumu & $94.9 \pm 96.1^{\mathrm{a}}$ & $139.0 \pm 109.6^{\mathrm{ab}}$ & $4.23 \pm 1.98^{\mathrm{a}}$ & $1.62 \pm 0.64^{\mathrm{a}}$ \\
Karaba & $49.6 \pm 42.3^{\mathrm{a}}$ & $130.0 \pm 69.6^{\mathrm{b}}$ & $2.70 \pm 1.52^{\mathrm{b}}$ & $1.53 \pm 0.69^{\mathrm{a}}$ \\
\hline Overall mean & $130.1 \pm 199.8^{\mathrm{a}}$ & $159.6 \pm 130.0$ & $2.66 \pm 1.77^{-}$ & $1.44 \pm 0.94$ \\
CV $(\%)$ & 154 & 81 & 67 & 64
\end{tabular}

Note. Means followed by the same superscript letter within a column are not significantly different at $\mathrm{p}<0.05$; SD: standard deviation, CV: coefficient of variation, Fe: iron, Mn: manganese, Cu: copper, Zn: zinc.

In our results, very wide variations in surface paddy soil micronutrient concentration were found. Surface soil Mn concentration ranged from $1.5 \mathrm{mg} / \mathrm{kg}$ to $849.2 \mathrm{mg} / \mathrm{kg}$, soil Fe concentration ranged from undetected to 1360.6 $\mathrm{mg} / \mathrm{kg}$, soil Cu concentration from undetected to $9.3 \mathrm{mg} / \mathrm{kg}$ and soil $\mathrm{Zn}$ from $0.1 \mathrm{mg} / \mathrm{kg}$ to $8.0 \mathrm{mg} / \mathrm{kg}$. The ranking order of micronutrient concentration in the MIS paddy soils was $\mathrm{Fe}>\mathrm{Mn}>>\mathrm{Cu}>\mathrm{Zn}$ indicating that soil $\mathrm{Fe}$ concentration followed by $\mathrm{Mn}$ were in higher concentrations compared to soil $\mathrm{Cu}$ and $\mathrm{Zn}$ concentrations.

Within the production units, surface soil Fe concentration varied from undetected to $1360.6 \mathrm{mg} / \mathrm{kg}$ in Mwea unit, soil $\mathrm{Mn}$ from 1.5 to $849.2 \mathrm{mg} / \mathrm{kg}$, soil $\mathrm{Cu}$ from undetected to $5.5 \mathrm{mg} / \mathrm{kg}$ and soil $\mathrm{Zn}$ from 0.1 to $8.0 \mathrm{mg} / \mathrm{kg}$. In Thiba unit, values varying between 22.1 and $795.4 \mathrm{mg} / \mathrm{kg}$ were recorded for soil $\mathrm{Fe}$, soil $\mathrm{Mn}$ from 63.6 to 504.3 $\mathrm{mg} / \mathrm{kg}$, soil $\mathrm{Cu}$ from 0.68 to $4.22 \mathrm{mg} / \mathrm{kg}$ while soil $\mathrm{Zn}$ ranged from 0.13 to $2.68 \mathrm{mg} / \mathrm{kg}$. In Tebere unit, soil Fe varied from 13.9 to $398.8 \mathrm{mg} / \mathrm{kg}$, soil $\mathrm{Mn}$ from 28.5 to $380.0 \mathrm{mg} / \mathrm{kg}$, soil Cu from 0.18 to $4.5 \mathrm{mg} / \mathrm{kg}$ and soil $\mathrm{Zn}$ from 0.3 to $2.57 \mathrm{mg} / \mathrm{kg}$. Further lower the irrigation scheme in Wamumu, surface soil Fe ranged from 16.3 to $433.0 \mathrm{mg} / \mathrm{kg}$, soil $\mathrm{Mn}$ from 41.4 to $433.2 \mathrm{mg} / \mathrm{kg}$, soil $\mathrm{Cu}$ from 0.96 to $9.29 \mathrm{mg} / \mathrm{kg}$ and $\mathrm{Zn}$ from 0.38 to 2.77 $\mathrm{mg} / \mathrm{kg}$. In Karaba at the end of the scheme, soil Fe ranged from 0.5 to $226.8 \mathrm{mg} / \mathrm{kg}$, soil Mn from 35.7 to 292.9 $\mathrm{mg} / \mathrm{kg}$ and 0.23 to $6.78 \mathrm{mg} / \mathrm{kg}$ for soil $\mathrm{Cu}$ whereas soil $\mathrm{Zn}$ ranged from 0.35 to $3.69 \mathrm{mg} / \mathrm{kg}$. In general, except for soil $\mathrm{Fe}$ and $\mathrm{Mn}$, soil $\mathrm{Cu}$ and $\mathrm{Zn}$ concentration showed an increasing trend from the higher elevation Mwea unit to the lower elevation units of Wamumu and Karaba. This can be attributed to the irrigation water flow that carries dissolved $\mathrm{Zn}$ and $\mathrm{Cu}$ depositing them in the receiving depression areas as the slope gradient decreases. Although statistical analysis indicted lack of significant differences in soil Fe concentration, $\mathrm{CV}$ values depicted a highly 
heterogeneous irrigation scheme with $154 \%, 81 \%, 67 \%$ and $64 \%$ for $\mathrm{Fe}, \mathrm{Mn}, \mathrm{Cu}$ and $\mathrm{Zn}$ respectively. The variability observed in the micronutrient concentration could be attributed to the differences in land management practices and other anthropogenic activities.

Micronutrients are involved in the entire metabolic enzyme system of plants. The range between toxic and deficient levels is often very small; thus a proper supply of micronutrients is essential for good plant growth. The electrochemical and biochemical changes caused by submergence are known to directly and indirectly influence the solubility and availability of micronutrients in the soil (Neue \& Mamaril, 1985) and therefore care must be taken in maintaining the right soil condition to avoid the adverse effects of micronutrient stresses in the soil.

\subsubsection{Soil Fe Concentration}

In soils, Fe occurs mainly in oxides and hydroxides forms as small particles or associated in amorphous form with the surfaces of other minerals. In horizons rich in organic matter, it appears to be in chelated forms (Kabata-Pendias, 2011). In paddy soils, Fe is one of the most notable elements because it is abundant and undergoes redox transformation (Kyuma, 2004). It is required for electron transport in photosynthesis and its solubility is known to increase after flooding when it is reduced to a more soluble form during organic matter decomposition (Dobermann \& Fairhurst, 2000). In rice production, Fe deficiency occurs when the soil concentration is below $4-5 \mathrm{mg} / \mathrm{kg}$ while toxicity occurs when the soil Fe concentration is above $300 \mathrm{mg} / \mathrm{kg}$ (Dobermann \& Fairhurst, 2000). In our site, it is likely that stresses related to Fe toxicities and deficiencies can be experienced given the minimum and maximum values recorded.

Fe deficiency is likely to occur in the Mwea and Karaba unit fields where minimum values of below 4-5 $\mathrm{mg} / \mathrm{kg}$ were recorded in about 3\% of fields from each unit. In rice production, Fe deficiency is known to occur in soils with low concentration of soluble $\mathrm{Fe}$ and high $\mathrm{pH}$ as well as lowland soils irrigated with alkaline irrigation water (Fairhurst, Witt, Buresh, \& Dobermann, 2007). In the United States, Zekri and Obreza (2015) noted that Fe deficiency was common on Florida's calcareous soils with high soil $\mathrm{pH}$. Calcareous soils could be containing appreciable amounts of $\mathrm{Fe}$ but the fact that the soils are high in calcium carbonate concentration, Fe in such soils exists in forms unavailable for plants uptake. Apart from high alkalinity and low soil Fe concentration, high $\mathrm{P}$ levels, poor drainage causing prolonged wet soil conditions and low soil temperature are also associated with $\mathrm{Fe}$ deficiency (Zekri \& Obreza, 2015). In the possible Fe deficiency fields from the MIS, both low soil Fe and alkalinity are factors likely to lead to Fe deficiency stress because high $\mathrm{pH}$ values were also recorded. Generally in the MIS, high Ca concentrations in the soil were observed (Kundu et al., 2016) which contribute to the high soil $\mathrm{pH}$ values. Poor drainage where in most cases farmers leave the fields flooded for longer periods of time (1-3 months) before transplanting as observed by Kondo et al. (2001) could also aggravate Fe deficiency stresses.

On the other hand, toxicity is mainly caused by the toxic effects of excessive Fe uptake by the rice plant because of a large concentration of $\mathrm{Fe}$ in the soil solution and is known to occur on a wide range of soils with $\mathrm{pH}$ values 4-7; but is generally high in lowland rice soils with permanent flooding during crop growth (Yoshida, 1981; van Mensvoort, Lantin, Brinman, \& Breemen, 1985; Neue, Quijano, Senadhira, \& Setter, 1998; Fairhurst et al., 2007). Generally, high levels of soil Fe concentration and low $\mathrm{pH}$ has been associated with toxicity (Fageria et al., 1990). In the MIS, Fe toxicity stress is likely to occur in a number of fields in the Mwea unit (22\%), Thiba unit $(20 \%)$ and to a lesser extent in Tebere unit $(6 \%)$ and Wamumu unit $(5 \%)$ where maximum soil Fe values exceeded the $300 \mathrm{mg} / \mathrm{kg}$ limit for rice growth. The reasonable likelihood of Fe toxicity stress as observed for Mwea unit (22\%) concur with earlier findings by Kondo et al. (2001) who noted moderately high presence of free $\mathrm{Fe}$ oxides in the unit. In our results, the soils of Mwea unit generally had moderately low $\mathrm{pH}$ and this could further exacerbate $\mathrm{Fe}$ toxicities in the unit. Moreover, a study on the physical and chemical analysis of Mwea region clays showed Fe as a major contaminant occurring at 12-16\% (Muriithi, Karoki, \& Gachanja, 2012).

Fe toxicity is said to be a likely serious problem in many parts of the world such as Africa, South America and Asia especially where rice is grown on acid soils that have great potential for rice production (Fageria, Baligar, \& Wright, 1990). Yield losses associated with Fe toxicity in rice commonly range from $15 \%$ to $30 \%$; but complete crop failure has been reported to occur under severe toxicity (Audebert \& Sahrawat, 2000). In West Africa, Fe toxicity caused a yield reduction of about $40-45 \%$ although the extent of yield loss depended on rice cultivar, iron toxicity intensity and crop management strategies in terms of water control and mineral fertilization (Audebert \& Fofana, 2009). Soil and water conditions that prevail in inland valley swamps and other wetlands such as irrigated lowlands and rain fed lowlands are known to lead to the development of iron toxicity in rice (Becker \& Asch, 2005). It has been observed that in Africa, soils with high levels of Fe toxicities in rice occur in 
many inland valleys and irrigated fields (Narteh \& Sahrawat, 1999; Abah et al., 2012) and yield losses of 12$100 \%$ have been reported in West Africa (Sahrawat et al., 1996; Sahrawat, 2004).

Elevated Fe concentration in the soil solution has been shown to decrease the absorption of other plant nutrients especially P and K by the rice plant (Yoshida, 1981; Olaleye, Tabi, Ogunkunle, Singh, \& Sahrawat, 2001) and as such, application of plant nutrients that could be limiting such as $\mathrm{P}, \mathrm{K}, \mathrm{Ca}, \mathrm{Mg}$ and $\mathrm{Zn}$ may alleviate iron toxicity effects by enhancing plant tolerance (Tanaka, Loe, \& Navasero, 1966). Toxicity stress can also be countered by using Fe-tolerant rice genotypes as well as through proper soil, water and nutrient management practices (Sahrawat, 2004) although under high iron toxicity stress, an integrated use of tolerant cultivars and improved soil and nutrient management give the best results (Sahrawat et al., 1996). Audebert and Fofana (2009) reiterated that the application of $\mathrm{P}, \mathrm{K}$ and $\mathrm{Zn}$ in conjunction with $\mathrm{N}$ is an effective way of reducing Fe toxicity effects on rice growth and yield.

In soil, micronutrient cations are known to be most stable and available under acid (low $\mathrm{pH}$ ) conditions and as the $\mathrm{pH}$ increases, their ionic forms are changed into insoluble and unavailable forms (Brady \& Weil, 2014). The decrease in surface soil Fe concentration at lower elevation as observed in our study is because in paddy fields, $\mathrm{Fe}$ as well as Mn tends to accumulate below the plough layer in the subsoil as water percolates. Leaching of nutrients from the plough layer by water percolation and their accumulation in the subsoil has been observed in a Japanese paddy field by Katoh, Murase, Hayashi, Matsuya, and Kimura (2004a). In a separate study, Katoh, Murase, and Kimura (2004b) also demonstrated the accumulation of Fe in the uppermost part of the subsoil. The decrease in top soil Fe concentration in the depression areas with decreased gradient of our study site is attributable to percolation to the subsoil through irrigation water and increase in surface soil $\mathrm{pH}$.

In the MIS, fields to be monitored for possible Fe toxicity or deficiency stresses are listed in Table 4.

Table 4. Unit fields likely to suffer Fe stress (toxicities or deficiencies)

\begin{tabular}{|c|c|c|c|c|c|}
\hline \multicolumn{3}{|c|}{ Fe toxicity $(>300 \mathrm{mg} / \mathrm{kg}$ soil concentration) } & \multicolumn{3}{|c|}{ Fe deficiency $(<4-5 \mathrm{mg} / \mathrm{kg}$ soil concentration $)$} \\
\hline Unit/field & $\mathrm{pH}_{\text {water }}$ & $\mathrm{Fe}(\mathrm{mg} / \mathrm{kg})$ & Unit/field & $\mathrm{pH}_{\text {water }}$ & $\mathrm{Fe}(\mathrm{mg} / \mathrm{kg})$ \\
\hline M1 & 5.12 & 1360.6 & M4 & 6.53 & nd \\
\hline M1 & 5.02 & 935.7 & M4 & 8.05 & 3.8 \\
\hline M4 & 5.31 & 1047.3 & K6 & 7.99 & 0.5 \\
\hline M4 & 5.40 & 313.4 & & & \\
\hline M4 & 5.40 & 363.2 & & & \\
\hline M4 & 5.02 & 556.6 & & & \\
\hline M9 & 4.87 & 808.9 & & & \\
\hline M11 & 4.95 & 535.6 & & & \\
\hline M11 & 4.95 & 376.2 & & & \\
\hline M11 & 4.56 & 707.4 & & & \\
\hline M11 & 5.07 & 326.9 & & & \\
\hline M11 & 5.36 & 416.6 & & & \\
\hline M11 & 4.85 & 339.0 & & & \\
\hline W1 & 5.64 & 346.0 & & & \\
\hline W7 & 4.91 & 433.0 & & & \\
\hline $\mathrm{T} 8$ & 4.90 & 398.8 & & & \\
\hline H1 & 4.90 & 795.4 & & & \\
\hline H3 & 5.11 & 347.7 & & & \\
\hline
\end{tabular}

Note. M-Mwea unit, H-Thiba unit, K-Karaba unit, T-Tebere unit, nd-not detected.

\subsubsection{Soil Mn Concentration}

$\mathrm{Mn}$ is one of the most abundant trace elements in the lithosphere ranging from 350 to $2000 \mathrm{mg} / \mathrm{kg}$ where higher concentrations are associated with mafic rocks (Kabata-Pendias, 2011). According to her, the highest levels occur in loamy and calcareous soils. $\mathrm{Mn}$ as a micronutrient is involved in oxidation-reduction reactions in the electron transport system and oxygen evolution in photosynthesis. It is essential in activation of certain enzymes, protein synthesis and in formation and stability of chloroplasts. It is also important in mitigating Fe toxicity and 
its availability just like Fe increases with flooding (Dobermann \& Fairhurst, 2000). Deficiencies of $\mathrm{Mn}, \mathrm{Cu}$ and $\mathrm{B}$ are rare in rice and hence less research has been done on fixing their critical limits (Savithri, Perumal, \& Ngarajan, 1999), but a concentration of $3-30 \mathrm{mg} / \mathrm{kg}$ is used as the optimum soil $\mathrm{Mn}$ concentration and its application in unnecessary in soils with above $40 \mathrm{mg} / \mathrm{kg} 0.1 \mathrm{M} \mathrm{HCl}$ extractable Mn (Dobermann \& Fairhurst, 2000).

Mn deficiency stress occurs because of small quantities of soil available Mn coupled with large concentrations of $\mathrm{Ca}^{2+}, \mathrm{Mg}^{2+}, \mathrm{Zn}^{2+}$ etc as well as large Fe in the soil solution (Dobermann \& Fairhurst, 2000; Fairhurst et al., 2007). In lowland rice, Mn deficiency stress is uncommon because its solubility is said to increase in submerged conditions when it is reduced to plant-available forms (Dobermann \& Fairhurst, 2000; Fairhurst et al., 2007; Tao et al., 2007). In Florida, Mn deficiency has been observed on both acidic and alkaline soils and was attributed to leaching in acid soils and to insolubility in the alkaline soils (Zekri \& Obreza, 2015). In addition, it has been associated with deficiencies of $\mathrm{Zn}, \mathrm{Fe}$ and $\mathrm{Cu}$ on both acid and alkaline soils and with $\mathrm{Mg}$ deficiency on acidic sandy soils (Zekri \& Obreza, 2015). In Iran, Mn deficiency is recognized as an important nutritional problem in cereal production where it is known to occur on sandy soils with neutral to slightly alkaline $\mathrm{pH}$, soils from marine sediments and rich in carbonates as well as soils rich in clay and organic matter (Aref, 2010, 2012). In our site, Mn deficiency is unlikely to be a critical issue even though less than the optimum soil concentrations were recorded in some fields. This is because stresses related to Mn deficiency are said to be typically rare under flooded conditions because of the low soil redox potentials under such conditions (Tao et al., 2007). Nonetheless, preventive strategies to prevent Mn deficiencies include application of farm yard manure or returning crop residues which reduces $\mathrm{Mn}$ losses in the soil. The use of acid forming fertilizers such as ammonia sulphate as a fertilizer management strategy is also recommended (Dobermann \& Fairhurst, 2000; Fairhurst et al., 2007).

In rice production, $\mathrm{Mn}$ toxicity has been reported in lowlands with ground-water containing elevated amounts of $\mathrm{Mn}$ and soils with readily reducible $\mathrm{Mn}$ of more than $300 \mathrm{mg} / \mathrm{kg}$ (Kyuma, 2004). In a separate scenario, Kabata-Pendias (2011) observed that most plants are affected when soil Mn contents are around $500 \mathrm{mg} / \mathrm{kg}$ and $\mathrm{pH}$ of around 5.5 or lower. Nonetheless, the critical Mn content and unfavourable soil pH ranges depend upon several other environmental factors and toxicity is also known to occur at higher $\mathrm{pH}$ levels where soils are poorly aerated and poorly drained (Kabata-Pendias, 2011). Dobermann and Fairhurst (2000), and Fairhurst et al. (2007) however noted that Mn toxicity rarely occurs in lowland rice even with large Mn concentrations in soil solution because rice is said to be comparatively tolerant to large $\mathrm{Mn}$ concentrations. Mn toxicity stress is likely to occur on acid upland soils with $\mathrm{pH}$ values below 5.5 where $\mathrm{Al}$ toxicity also occurs; lowland soils with large amounts of easily reducible Mn, acid-sulphate soils and on areas affected by Mn mining as found in Japan (Dobermann \& Fairhurst, 2000; Fairhurst et al., 2007). From our findings, Mn toxicity stress is likely to be experienced in just about $1 \%$ of the sampled fields with all of them occurring in the higher elevation units of Mwea and Thiba. In these cases, the soil solution $\mathrm{pH}$ recorded was below 5.5 and soil $\mathrm{Mn}$ concentration was above $500 \mathrm{mg} / \mathrm{kg}$.

To mitigate against the negative Mn toxicity stress effects, proper fertilizer management should be taken into account. Application of lime on acid soils to reduce the concentration of active $\mathrm{Mn}$ and proper straw management should be embraced (Dobermann \& Fairhurst, 2000; Fairhurst et al., 2007). Similar to soil Fe, soil Mn tended to decrease in the surface soil down the elevation with Mwea and Thiba units at higher elevation recording higher surface soil Mn compared to the lower elevation Wamumu and Karaba units. Like Fe, Mn together with other nutrient elements in paddy fields percolates through irrigation water and accumulates in the subsoil (Katoh et al., 2004a). Additionally, Brady and Weil (2014) noted that micronutrients are most soluble and readily available under acid conditions and as the $\mathrm{pH}$ increases, they are changed into insoluble hydroxides or oxides therefore the decrease in Mn concentration down the elevation in our study site is attributed to its percolation through irrigation water and the increase in surface soil $\mathrm{pH}$.

\subsubsection{Soil $\mathrm{Cu}$ Concentration}

Generally, $\mathrm{Cu}$ is accumulated in the upper few centimetres of soils; however, due to its tendency to be adsorbed by soil organic matter, carbonates, clay minerals and oxyhydroxides of $\mathrm{Mn}$ and $\mathrm{Fe}$; it may be also accumulated in deeper soil layers (Kabata-Pendias, 2011). In soils, it is present as oxides, carbonates, silicates and sulphides and its chemistry in submerged soils is similar to that of Zn, forming sparingly soluble sulphides (Neue \& Mamaril, 1985). $\mathrm{Cu}$ is required for lignin synthesis and is a constituent of ascorbic acid and as well as some enzymes. It is a regulatory factor in enzyme reactions and a catalyst in oxidation reactions. As a micronutrient, it plays a key role in nitrogen, protein and hormone metabolism, pollen formation and fertilization as well as photosynthesis and respiration (Dobermann \& Fairhurst, 2000; Fairhurst et al., 2007; Kabata-Pendias, 2011). It is observed that sandy, calcareous, lateritic soils and high organic matter induce $\mathrm{Cu}$ deficiencies (Das, 2014). In our study, $\mathrm{Cu}$ soil concentrations are sufficient as they are above critical deficiency levels of $0.1 \mathrm{mg} / \mathrm{kg}$ for rice production 
(Dobermann \& Fairhurst, 2000; Fairhurst et al., 2007). Cu availability decreases at flooding as a result of the formation of copper sulfides and ferrite and further complexes with organic matter. As a result, its availability for plant uptake decreases with increase in pH (Dobermann \& Fairhurst, 2000; Fairhurst et al., 2007). In Mwea irrigation scheme therefore there is neither risk of $\mathrm{Cu}$ deficiency nor toxicity given that its solubility and availability decreases with flooding.

\subsubsection{Soil Zn Cconcentration}

$\mathrm{Zn}$ is essential for several biochemical processes in rice plant for instance enzyme activation and chlorophyll production. It promotes seed and grain formation, plant maturity and is essential for protein synthesis (Brady \& Weil, 2014). It is accessible to plants as exchangeable $\mathrm{Zn}^{2+}$ ions but most of the ions are bound to clay particles or inorganic constituents like iron and aluminium oxides and thus unavailable for plant uptake. It is also known to chelate and bind to organic matter which can be decomposed and release ions for plant uptake (Brady \& Weil, 2014). In soil solution, $\mathrm{Zn}$ is reported to be generally of low mobility because of the tendency to be adsorbed on clay size particles (Alloway, 2008; Kabata-Pendias, 2011). In rice production, $2.0 \mathrm{mg} / \mathrm{kg} 0.1 \mathrm{~N} \mathrm{HCl}$-extractable is set as the critical level for deficiency to occur (Dobermann \& Fairhurst, 2000; Fairhurst et al., 2007). In our results although there was an increasing trend in soil $\mathrm{Zn}$ down the slope, high variations existed with about $80 \%$ of the sampled fields recording below the $2.0 \mathrm{mg} / \mathrm{kg}$ critical soil limit. On average all the units in the MIS showed deficiency in soil $\mathrm{Zn}$ concentration $(<2.0 \mathrm{mg} / \mathrm{kg})$. Such high incidences of $\mathrm{Zn}$ deficiency stress have also been reported on Ethiopian Vertisols (Kebede \& Yamoah, 2009; Hailu et al., 2015) and in West African lowlands (Abe, Buri, Issaka, Kiepe, \& Wakatsuki, 2010).

As an essential plant micronutrient, $\mathrm{Zn}$ has been shown to be the most critical yield limiting micronutrient to rice growth after N (Neue \& Mamaril, 1985; Alloway, 2008; Buri, Masunaga, \& Wakatsuki, 2000). Zn deficiency has been shown to decrease cereal yields by as much as $50 \%$ according to work done by van Asten, Barro, Wopereis, and Defoer (2004). Under severe Zn deficiency, tillering of rice is affected and may stop completely; spikelet sterility is also known to increase (Dobermann \& Fairhurst, 2000) which has a negative effect on grain yield (Yang, Shi, Xu, Lu, \& Wang, 2009). In Japan, Zn deficiency stress causes a disorder known as 'Akarage Type II' that damages rice crop throughout its growth cycle (Dobermann \& Fairhurst, 2000). Zn deficiency stress is said to occur on a wide range of soils in combination with several other contributing factors. Soils low in $\mathrm{Zn}$ concentration, high in available $\mathrm{P}$ and $\mathrm{Si}$ as well as leached, aged acid-sulphate, sodic soils, saline-neutral soils, calcareous, peat, sandy, highly weathered acid and course textured soils are said to be prone to Zn deficiency (Dobermann \& Fairhurst, 2000; Kyuma, 2004; Fairhurst et al., 2007; Alloway, 2008, 2009). Under flooded soil condition, $\mathrm{Zn}$ availability decreases compared to well-aerated soils and when prolonged, the deficiency is exacerbated by the formation of sulpahtes and carbonates (Neue \& Mamaril, 1985; Neue \& Bloom, 1989). Furthermore, the high carbonate concentration especially in calcareous soils, high $\mathrm{pH}$ under anaerobic conditions as well as increased availability of $\mathrm{Ca}, \mathrm{Mg}, \mathrm{Fe}, \mathrm{Mn}, \mathrm{Cu}$ and $\mathrm{P}$ after flooding bring about $\mathrm{Zn}$ deficiencies (Dobermann \& Fairhurst, 2000; Fairhurst et al., 2007). Excessive P fertilizer application causes Zn immobilization in the soil thus making it unavailable for plant uptake (Dobermann \& Fairhurst, 2000; Fairhurst et al., 2007).

In the MIS, the low soil available $\mathrm{Zn}$ and the calcareous nature of the soils are factors contributing majorly to the widespread $\mathrm{Zn}$ deficiency stress. Famers in the scheme rarely use micronutrient fertilizer and in most cases they apply $\mathrm{N}$ and $\mathrm{P}$ fertilizers (Kihoro et al., 2013). In this regard, management practices to help alleviate $\mathrm{Zn}$ deficiency stress would be to introduce Zn-based fertilizers and using fresh water for irrigation especially in the receiving depression units to reduce on the carbonate accumulation. Where possible, selection of Zn-efficient varieties and application of organic manure or Zn fertilizers before seeding or transplanting are other helpful management strategies to explore as suggested by Fairhurst et al. (2007).

\subsection{Relationship between Soil pH and Micronutrient Concentration}

To examine the relationship between soil micronutrient concentration and soil $\mathrm{pH}$, a Pearson correlation analysis was performed. Correlation analysis result for Mwea irrigation scheme soil $\mathrm{pH}$ and micronutrient concentration is shown in Table 5. 
Table 5. Pearson correlation between soil micronutrient concentration and $\mathrm{pH}$

\begin{tabular}{lllllll}
\hline & $\mathrm{pH}_{\text {water }}$ & $\mathrm{pH}_{\mathrm{KCl}}$ & $\mathrm{Cu}$ & $\mathrm{Fe}$ & $\mathrm{Mn}$ & $\mathrm{Zn}$ \\
\hline $\mathrm{pH}_{\text {water }}$ & $.975^{* *}$ & & & & & \\
$\mathrm{pH}$ KCl & -.078 & -.053 & & & & \\
$\mathrm{Cu}$ & $-.594^{* *}$ & $-.585^{* *}$ & $.143^{*}$ & & & \\
$\mathrm{Fe}$ & $-.382^{* *}$ & $-.361^{* *}$ & -.064 & $.455^{* *}$ & & \\
$\mathrm{Mn}$ & $-.422^{* *}$ & $-.392^{* *}$ & $.143^{*}$ & $.565^{* *}$ & $.238^{* *}$ & \\
$\mathrm{Zn}$ & &
\end{tabular}

Note. $* *$ and $*$ Correlation is significant at the 0.01 and 0.05 level.

There was a significant negative correlation between soil solution $\mathrm{pH}$ and $\mathrm{Fe}, \mathrm{Mn}$ and $\mathrm{Zn}$ except with $\mathrm{Cu}$ that showed a negative insignificant correlation. Soil solution $\mathrm{pH}_{\text {water }}$ showed a very good correlation with $\mathrm{pH}_{\mathrm{KCl}}(\mathrm{r}=$ $0.975, p<0.01)$. All micronutrients showed significant positive correlation with each other except for $\mathrm{Mn}$ and $\mathrm{Cu}$ that showed an insignificant and negative correlation.

Plant uptake of micronutrients is mainly dependent on their mobility and availability in soils (Zeng et al., 2011). According to Kashem and Singh (2001) and Antoniadis, Robinson, and Alloway (2008), the adsorption and desorption of heavy metals has been associated with soil properties including $\mathrm{pH}$, organic matter content, cation exchange capacity (CEC), oxidation-reduction status (Eh), calcium carbonate and $\mathrm{Fe}$ and $\mathrm{Mn}$ oxides among others. Of these soil properties, soil $\mathrm{pH}$ was found to play the most important role in determining metal speciation, solubility, movement and eventual bioavailability due to its strong effects on solubility and speciation of the metals in the soil solution (Zhao, Liu, Xua, \& Selim, 2010). Soil pH is an important chemical property governing the availability of nutrients in the soil nutrient pool. It plays an important role in soil microbial activity and decomposition of mineral substances and organic matter; thus influences the release, fixation and migration of soil nutrients (Fageria \& Baligar, 1999).

During rice cultivation when an aerobic soil is initially submerged, the entire soil layer is reduced, redox potential is lowered and there is an increase in ferrous iron and ammoniacal nitrogen coupled with a decrease in pH (Ponnamperuma, 1985; Kyuma, 2004). With time, the formation of ammoniacal nitrogen subsides, the amount of ferrous iron decreases, the redox potential increases and the $\mathrm{pH}$ increases asymptotically. The substances liberated during the reduction process become adsorbed onto soil surface or are dissolved in soil solution as anions and thus increasing soil $\mathrm{pH}$ towards alkaline (Kyuma, 2004). As the soil $\mathrm{pH}$ increases, so does ionic strength which depresses activity coefficients and alters the concentrations of ecologically important ions in the soil solution (Ponnamperuma, 1985). The antagonistic relationship between soil $\mathrm{pH}$ and heavy metal as reported in our study is similar to what has been documented in studies elsewhere for instance Speir, Schaik, Percival, Close, and Pang (2003), Wang, Angle, Chaney, Delome, and Reeves (2006), and Aref (2012).

Generally, micronutrients $\mathrm{Zn}, \mathrm{Cu}, \mathrm{Fe}$ and $\mathrm{Mn}$ are said to be greatly available in slightly acidic to neutral $\mathrm{pH}$ soils but are much less available at pH above 7 (Fageria, Slaton, \& Baligar, 2003; Fageria, Caryalho, Santos, Ferraira, \& Knupp, 2011; Aref, 2012; Brady \& Weil, 2014). As the $\mathrm{pH}$ is increased, the ionic forms of the micronutrients are changed to hydroxyl ions and then to unavailable insoluble hydroxides or oxides. However, the exact $\mathrm{pH}$ at which precipitation occurs varies from element to element (Brady \& Weil, 2014). Studies by Wang et al. (2006) and Du Laing, Rinklebe, Vandecasteele, Meers, and Tack (2009) have also demonstrated that the mobility and bioavailability of heavy metals increase with decreased soil $\mathrm{pH}$. In acidic soil, $\mathrm{Mn}$ and Fe solubility has been shown to increase with flooding due to reductive dissolution of their hydroxides/oxides and decreased during drainage because of re-oxidation (Pan et al., 2014; Brady \& Weil, 2014).

Taking into account the negative correlation between soil $\mathrm{pH}$ and micronutrients, it can be deduced that soil $\mathrm{pH}$ has a depressing effect on availability of micronutrients and therefore it is imperative to have the proper soil solution $\mathrm{pH}$ maintained. While reviewing the soil fertility potential for rice production in West Africa, Abe et al. (2010) urged that appropriate soil $\mathrm{pH}$ should be maintained as micronutrient availability is greatly affected by soil $\mathrm{pH}$. Furthermore, there should be sufficient nutrient supply in the soil and in particular sufficient supply of $\mathrm{Zn}$ in the MIS through $\mathrm{Zn}$ fertilizers to avert the negative $\mathrm{Zn}$ deficiency stresses. Other strategies for $\mathrm{Zn}$ deficiency management should focus on proper irrigation water and manure/fertilizer management. In improving the drainage situation, periodic draining of the waterlogged rice fields should be practiced to avoid excessive accumulation of metal elements especially Fe in the soil. Delayed planting on flooded fields for atleast over 20 days after flooding has also been shown to reduce Fe accumulation in the soils. 


\section{Conclusions and Recommendations}

Rice yields in MIS do not exceed 5 ton/ha; which is far below the optimum of about 10 ton/ha (MoA, 2009). Statistical analysis showed that soil $\mathrm{Fe}, \mathrm{Mn}, \mathrm{Zn}$ and $\mathrm{Cu}$ had high $\mathrm{CV}$ s indicating high variability but low for $\mathrm{pH}$ indicating low variability hence a serious challenge to homogenous nutrient management recommendations. The micronutrients are obviously enriched in some parts of the studied soils and slightly or least enriched in some areas thus likely to cause toxicity and deficiency stresses. From the present study, the MIS Vertisols of Kenya showed both excess and insufficiencies in the levels of $\mathrm{Fe}$ and $\mathrm{Mn}$, deficiencies in $\mathrm{Zn}$ levels and adequacy in the levels of $\mathrm{Cu}$. The micronutrient deficiencies observed are due to their inherently low concentration in the soils as a consequence of continuous cropping without applying fertilizer or manure containing them. There is need for further studies to determine rice response to proper and balanced fertilization in this area. Farmers should be provided for and made aware of the benefits of inorganic fertilizers other than the $\mathrm{N}$ and $\mathrm{P}$ fertilizers in improving soil fertility, soil nutrient status and crop production. Application of appropriate field management approaches could help avert the negative toxicity and deficiency effects. Mid-season drainage to help aerate the soil and remove accumulated Fe and Mn could help avert toxicity stress. To correct $\mathrm{Zn}$ deficiencies, $\mathrm{Zn}$ fertilizers should be applied in combination with other macronutrient fertilizers. Straw return should also be encouraged as most of the farmers tend to remove all the straw after harvest which exacerbates nutrient mining from the farms.

\section{Acknowledgements}

We are deeply indebted to the Japan Science and Technology Agency (JST) and the Japan International Cooperation Agency (JICA) for funding the study through the Science and Technology Research Partnership for Sustainable Development program (SATREPS). Many thanks to the project staff in Mwea, Mwea Irrigation and Agricultural Development centre (MIAD), KALRO-Mwea and all the rice farmers for providing an enabling environment and support during soil sampling.

\section{References}

Abah, J., Umar, A., Bashir, M., Drame, K. N., Manneh, B., Abo, M. E., \& Sie, M. (2012). Soil characteristics of three iron toxic sites in Nigeria. Journal of Science and Multidisciplinary Research, 4.

Abdullahi, M., Mizutani, M., Tanaka, S., Goto, A., \& Matsui, H. (2003). Changes in water management practices in the Mwea Irrigation Scheme Kenya from 1994 to 1998. Rural and Environmental Engineering, 44(8), 60-67.

Abe, S. S., Buri, M. M., Issaka, R. N., Kiepe, P., \& Wakatsuki, T. (2010). Review: Soil fertility potential for rice production in West African lowlands. JARQ, 44(4), 343-355. https://doi.org/10.6090/jarq.44.343

Abu, S., \& Malgwi, W. (2011). Spatial variability of soil physico-chemical properties in Kadawa Irrigation project in Sudan Savanna agroecology of Nigeria. Int. J. Agric. Res., 6(10), 714-735. http://dx.doi.org/10.3923/ ijar.2011.714.735

Addis, H. K., Klik, A., \& Strohmeier, S. (2015). Spatial variability of selected soil attributes under agricultural land use system in a mountainous watershed, Ethiopia. International Journal of Geosciences, 6, 605-613. http://dx.doi.org/10.4236/ijg.2015.66047

Aimrun, W., Amin, M. S. M., Ahmad, D., Hanafi, M. M., \& Chan, C. S. (2007). Spatial variability of bulk soil electrical conductivity in a Malaysian Paddy Field: Key to Soil Management. Paddy Water Environ., 5, 113-121. http://dx.doi.org/10.1007/s10333-007-0072-z

Alloway, B. J. (2008). Zinc in Soils and Crop Nutrition (2nd ed.). IFA and IFIA, Brussels, Belgium and Paris, France.

Alloway, B. J. (2009). Soil factors associated with zinc deficiency in crops and humans. Environ Geochem Health, 31, 537-548. https://doi.org/10.1007/s10653-009-9255-4

Antoniadis, V., Robinson, J. S., \& Alloway, B. J. (2008). Effects of short-term pH fluctuations on cadmium, nickel, lead and zinc availability to ryegrass in a sewage sludge-amended field. Chemosphere, 71, 759-764. https://doi.org/10.1016/j.chemosphere.2007.10.015

Aref, F. (2010). Influence of zinc and boron interaction on residual available iron and manganese in the soil after corn harvest. Am-Euras. J. Agric. \& Environ. Sci., 8(6), 767-772.

Aref, F. (2012). Manganese, iron and copper contents in leaves of maize plants (Zea mays L.) grown with different boron and zinc micronutrients. Afr. J. Biotechnol., 11(4), 896-903. 
Audebert, A., \& Fofana, M. (2009). Mineral toxicity stress, rice yield gap due to iron toxicity in West Africa. $J$. Agronomy \& Crop Science, 195, 66-76. https://doi.org/10.1111/j.1439-037X.2008.00339.x

Audebert, A., \& Sahrawat, K. L. (2000). Mechanisms of iron toxicity tolerance in lowland rice. J. Plant Nutr., 23, 1877-1885. https://doi.org/10.1080/01904160009382150

Becker, M., \& Asch, F. (2005). Iron toxicity in rice-conditions and management concepts. J. Plant Nutri. Soil, 168, 558-573. https://doi.org/10.1002/jpln.200520504

Bell, R. W., \& Dell, B. (2008). Micronutrients for Food, Feed, Fibre and Bioenergy Production. International Fertilizer Industry Association (IFA), Paris, France.

Brady, W. C., \& Weil, R. R. (2014). The Nature and Properties of Soil (14th ed.). Pearson New International Edition.

Buri, M. M., Masunaga, T., \& Wakatsuki, T. (2000). Sulfur and zinc levels as limiting factors to rice production in West Africa lowlands. Geoderma, 94, 23-42. https://doi.org/10.1016/S0016-7061(99)00076-2

Cholarajan, A., \& Vijayakumar, R. (2013). Status of micronutrients in terrestrial soils of Thanjavur district, Tamilnadu, India. J. Agric. Res. Dev., 3(4), 059-063.

Das, S. K. (2014). Role of micronutrient in rice cultivation and management strategy in organic agriculture: A reappraisal. Agricultural Sciences, 5, 765-769. https://doi.org/10.4236/as.2014.59080

Dobermann, A., \& Fairhurst, T. H. (2000). Rice: Nutrient disorders and nutrient management (Vol. 1). International Rice Research Institute, Manila, Philippines.

Du Liang, G., Rinklebe, J., Vandecasteele, B., Meers, E., \& Tack, F. M. G. (2009). Trace metal behaviour in estuarine and riverine floodplain soils and sediments: A review. Science of the Total Environment, 407, 3972-3985. https://doi.org/10.1016/j.scitotenv.2008.07.025

European Cooperative for Rural Development [EUCORD]. (2012). Rice Sector Development in East Africa, A desk study prepared for the Common Fund for Commodities. European Cooperative for Rural Development

Fageria, N. K., \& Baligar, V. C. (1999). Growth and Nutrient Concentrations of Common Bean, Lowland Rice, Corn, Soybean and Wheat at Different Soil $\mathrm{pH}$ on an Inceptisol. Journal of Plant Nutrition, 22(9), 1495-1507. http://dx.doi.org/10.1080/01904169909365730

Fageria, N. K., Baligar, V. C., \& Wright, R. J. (1990). Iron Nutrition of plants: An overview on the chemistry and physiology of its deficiency and toxicity. Pesq. Agropec. Bras., Brasilia, 25(4), 553-570.

Fageria, N. K., Caryalho, G. D., Santos, A. B., Ferraira, E. P. B., \& Knupp, A. M. (2011). Chemistry of Lowland Rice Soils and Nutrient Availability. Communications in Soil Science and Plant Analysis, 42, 1913-1933. http://dx.doi.org/10.1080/00103624.2011.591467

Fageria, N. K., Slaton, N. A., \& Baligar, V. C. (2003). Nutrient Management for improving lowland rice productivity and sustainability. Advances in Agronomy, 80, 63-152. https://doi.org/10.1016/S0065-2113 (03)80003-2

Fairhurst, T. H., Witt, C., Buresh, R. J., \& Dobermann, A. (Eds.). (2007). Rice: A Practical Guide to Nutrient Management (2nd ed.). International Rice Research Institute, International Plant Nutrition Institute and International Potash Institute, Manila, Philippines.

Hailu, H., Mamo, T., Keskinen, R., Karltun, E., Gebrekidan, H., \& Bekele, T. (2015). Soil fertility status and wheat nutrient content in Vertisol cropping systems of central highlands of Ethiopia. Agric. \& Food Secur., 4, 19. https://doi.org/10.1186/s40066-015-0038-0

Ijumba, J. N., Mwangi, R., \& Beier, J. C. (1990). Malaria transmission potential of Anopheles mosquitoes in Mwea-Tebere Irrigation Scheme, Kenya. Med. Vet. Entomol., 4, 425-432. https://doi.org/10.1111/j.13652915.1990.tb00461.x

International Institute of Tropical Agriculture [IITA]. (1979). Selected Methods for Soil and Plant Analysis. Manual Series No. 1. International Institute of Tropical Agriculture, Ibadan, Nigeria.

Kabata-Pendias, A. (2011). Trace elements in soils and plants (4th ed.). CRC Press, Taylor and Francis Group, LLC.

Kabutha, C., \& Mutero, C. (2002). From government to farmer-managed smallholder rice schemes: The unresolved case of the Mwea Irrigation Scheme. In H. G. Blank, et al. (Eds.), The changing face of 
irrigation in Kenya: Opportunities for anticipating changes in Eastern and Southern Africa (pp. 191-210). Colombo, Sri Lanka, IWMI.

Kashem, M. A., \& Singh, B. R. (2001). Metal availability in contaminated soils: I. Effects of flooding and organic matter on changes in Eh, $\mathrm{pH}$ and solubility of $\mathrm{Cd}, \mathrm{Ni}$ and $\mathrm{Zn}$. Nutrient Cycling in Agroecosystems, 61, 247-255. https://doi.org/10.1023/A:1013762204510

Katoh, M., Murase, J., Hayashi, M., Matsuya, K., \& Kimura, M. (2004a). Nutrient leaching from the plow layer by water percolation and accumulation in the subsoil in an irrigated paddy field. Soil Sci. Plant Nutr., 50(5), 721-729. https://doi.org/10.1080/00380768.2004.10408528

Katoh, M., Murase, J., \& Kimura, M. (2004b). Sites and processes of nutrient accumulation in the subsoil through water percolation from the plow layer in a submerged paddy soil microcosm. Soil Sci. Plant Nutr., 50(5), 731-738. https://doi.org/10.1080/00380768.2004.10408529

Kawaguchi, K., \& Kyuma, K. (1974). Paddy Soils in Tropical Asia, Part 1: Description of Fertility Characteristics. Southeast Asian Studies, 12(1), 3-24.

Kebede, F., \& Yamoah, C. (2009). Soil fertility status and Numass fertilizer recommendation of Typic Hapluusterts in the Northern Highlands of Ethiopia. World Applied Sciences Journal, 6(11), 1473-1480.

Kenya Soil Survey [KSS]. (1987). Manual for Soil Survey and Land Evaluation (Vol. 1). Soil Survey, Miscellaneous Soil Paper No. M24. Kenya Soil Survey, KARI.

Kihoro, J., Bosco, N. J., Murage, H., Ateka, E., \& Makihara, D. (2013). Investigating the Impact of Rice Blast Disease on the Livelihood of the Local Farmers in Greater Mwea Region of Kenya. SpringerPlus, 2013(2), 308. http://dx.doi.org/10.1186/2193-1801-2-308

Kihoro, J., Njoroge, J. B., \& Hunja, M. (2013). Suitability analysis for rice growing sites using a multicriteria evaluation and GIS approach in great Mwea region, Kenya. SpringerPlus, 2013(2), 265. https://doi.org/ 10.1186/2193-1801-2-265

Kondo, M., Toshinari, O. T. A., \& Wanjogu, R. (2001). Physical and Chemical Properties of Vertisols and Soil Nutrient Management for Intensive Rice Cultivation in the Mwea Area in Kenya. Jpn. J. Trop. Agric., 45(2), 126-132.

Kundu, C. A., Ishii, M., Sato, K., Masunaga, T., Wanjogu, R. K., Njagi, R. E., ... Makihara, D. (2016). Evaluation of soil chemical properties under paddy production system in Central Kenya: Soil exchangeable cations. Journal of Agricultural Science, 8(8), 136-148. http://dx.doi.org/10.5539/jas.v8n8p136

Kyuma, K. (2004). Paddy Soil Science. Kyoto University Press, Kyoto.

Li, B. Y., Zhou, D. M., Cang, L., Zhang, H. L., Fan, X. H., \& Qin, S. W. (2007). Soil micronutrient availability to crops as affected by long-term inorganic and organic fertilizer applications. Soil and Tillage Research, 96, 166-173. https://doi.org/10.1016/j.still.2007.05.005

Liu, X. M., Xu, J. M., Zhang, M. K., Huang, J. H., Shi, J. C., \& Yu, X. F. (2004). Application of geostatistics and GIS technique to characterize spatial variabilities of bioavailable micronutrients in paddy soils. Environmental Geology, 46, 189-194. https://doi.org/10.1007/s00254-004-1025-0

McLean, E. O. (1982). Soil pH and lime requirement. In A. L. Page, R. H. Miller, \& D. R. Keeney (Eds.), Methods of soil analysis Part 2: Chemical and microbiological properties (2nd ed.), Agronomy (Vol. 9, pp. 199-223).

Ministry of Agriculture [MoA]. (2009). National Rice Development Strategy 2008-2018. Republic of Kenya.

Muhunyu, J. G. (2012). Is Doubling Rice Production in Kenya by 2018 Achievable? Journal of Developments in Sustainable Agriculture, 7, 46-54.

Mukiama, T. K., \& Mwangi, R. W. (1989). Field Studies of larval Anopheles arabiensis Patton of Mwea Irrigation Scheme, Kenya. International Journal of Tropical Insect Science, 10(1), 55-62. http://dx.doi.org/10.1017/S1742758400003349

Muriithi, N. T., Karoki, K. B., \& Gachanja, A. N. (2012). Chemical and mineral analyses of Mwea clays. Int. J. Phys. Sci., 7, 5865-5869.

Murthy, R. S., Bhattacharjee, J. C., Landey, R. J., \& Pofali, R. M. (1982). Distribution, characteristics and classification of Vertisols. In Transactions of the $12^{\text {th }}$ International Congress of Soil Science, Managing Soil Resources to Meet the Challenges to Mankind, Vertisols and Rice Soils of the Tropics. New Delhi, India. 
Narteh, L. T., \& Sahrawat, K. L. (1999). Influence of flooding on electrochemical and chemical properties of West African soils. Geoderma, 87, 197-207. https://doi.org/10.1016/S0016-7061(98)00053-6

Ndiiri, J. A., Mati, B. M., Home, P. G., \& Odongo, B. (2013). Water Productivity under the System of Rice Intensification from Experimental Plots and Farmer Surveys in Mwea, Kenya. Taiwan Water Conservancy, 61(4).

Neue, H. E., \& Mamaril, C. P. (1985). Zinc, sulfur, and other micronutrients in wetland soils. Wetland Soils: Characterization, Classification and Utilization (pp. 307-319). IRRI, Los Banos, Laguna, Philippines.

Neue, H. U., \& Bloom, P. R. (1989). Nutrient kinetics and availability in flooded rice soils. Progress in irrigated rice research (pp. 173-190). International Rice Research Institute, Manila, Philippines.

Neue, H. U., Quijano, C., Senadhira, D., \& Setter, T. (1998). Strategies for dealing with micronutrient disorders and salinity in lowland rice systems. Field Crops Research, 56, 139-155. https://doi.org/10.1016/ S0378-4290(97)00125-1

Njagi, T. N. (2012). An Investigation into the Possibility of a Rice Green Revolution in Sub-Saharan Africa: Lessons from the Mwea Irrigation Scheme in Kenya (Unpublished Doctoral dissertation). National Graduate Institute for Policy Studies (GRIPS), Tokyo Japan.

Nyamai, M., Mati, B. M., Home, P. G., Odongo, B., Wanjogu, R., \& Thuranira, E. G. (2012). Improving land and water productivity in basin rice cultivation in Kenya through System of Rice Intensification (SRI). AgricEngInt: CIGR Journal, 14, 1-9.

Olaleye, A. O., Tabi, A. O., Ogunkunle, A. O., Singh, B. N., \& Sahrawat, K. L. (2001). Effect of toxic iron concentrations on the growth of lowland rice. J. Plant Nutr., 24, 441-457. https://doi.org/10.1081/PLN100104971

Osiname, O. A., Schulte, E. E., \& Corey, R. B. (1973). Soil tests for available copper and zinc in soils of Western Nigeria. Journal of the Science of Food and Agriculture, 24(11), 1341-1349. https://doi.org/10.1002/ jsfa.2740241105

Pan, Y., Koopmans, G. F., Bonten, L. T. C., Song, J., Luo, Y., Temminghoff, E. J. M., \& Comans, R. N. J. (2014). Influence of $\mathrm{pH}$ on the redox chemistry of metal (hydr) oxides and organic matter in paddy soils. Journal of Soils Sediments, 14(10), 1713-1726. https://doi.org/10.1007/s11368-014-0919-z

Ponnamperuma, F. N. (1985). Chemical kinetics of wetland rice soils relative to soil fertility. Wetland Soils: Characterization, Classification and Utilization (pp. 71-89). IRRI, Los Banos, Laguna, Philippines.

Rezaei, S. A., \& Gilkes, R. J. (2004). The effects of landscape attributes and plant community on soil chemical properties in rangelands. Geoderma, 125, 167-176. https://doi.org/10.1016/j.geoderma.2004.07.010

Rieuwerts, J. S., Ashmore, M. R., Farago, M. E., \&Thornton, I. (2006). The influence of soil characteristics on the extractability of $\mathrm{Cd}, \mathrm{Pb}$ and $\mathrm{Zn}$ in upland and moorland soils. Science of the Total Environment, 366, 864-875. https://doi.org/10.1016/j.scitotenv.2005.08.023

Rosemary, A. E., Bibiana, M. W., Njuguna, N., Dominic, M. K., \& Daniel, A. (2010). Rice Value Chain Study Report for Kenya. Ministry of Agriculture (MoA) and Kenya Agricultural Research Institute (KARI).

Sahrawat, K. L. (2004). Iron toxicity in wetland rice and the role of other nutrients. Journal of Plant Nutrition, 27, 1471-1504. https://doi.org/10.1081/PLN-200025869

Sahrawat, K. L., Mulbah, C. K., Diatta, S., De Laune, R. D., Patrick Jr, W. H., Singh, B. N., \& Jones, M. P. (1996). The role of tolerant genotypes and nutrients in the management of iron toxicity in lowland rice. Journal of Agricultural Sciences, Cambridge, 128, 146-149. https://doi.org/10.1017/s002185960007307x

Savithri, P., Perumal, R., \& Ngarajan, R. (1999). Soil and crop management technologies for enhancing rice production under micronutrient constraints. Nutrient Cycling in Agroecosystems, 53, 83-92. https://doi.org/ 10.1023/A:1009753729599

Sombroek, W. G., Braun, H. M. H., \& van der Pouw, B. J. A. (1982). The exploratory soil map of Kenya and Agro-Climatic Zone Map of Kenya scale 1:1 million. Exploratory Soil Survey Report No. E1. Kenya Soil Survey, Nairobi.

Speir, T. W., Schaik, A. P. V., Percival, H. J., Close, M. E., \& Pang, L. P. (2003). Heavy metals in soil, plants and groundwater following high-rate sewage sludge application to land. Water, Air and Soil Pollution, 150, 319-358. https://doi.org/10.1023/A:1026101419961 
Sun, B., Zhou, S., \& Zhao, Q. (2003). Evaluation of spatial and temporal changes of soil quality based on geostatistical analysis in the hill region of subtropical China. Geoderma, 115, 85-99. http://dx.doi.org/ 10.1016/S0016-7061(03)00078-8

Tanaka, A., Loe, R., \&Navasero, S. A. (1966). Some mechanisms involved in the development of iron toxicity symptoms in the rice plant. Soil Sci. Plant Nutr., 12(4), 32-38. https://doi.org/10.1080/00380768. 1966.10431951

Tao, H., Dittert, K., Zhang, L., Lin, S., Römheld, V., \& Sattelmacher, B. (2007). Effects of soil water content on growth, tillering and manganese uptake of lowland rice grown in the water-saving ground-cover rice-production system (GCRPS). J. Plant Nutr. Soil Sci., 170, 7-13. https://doi.org/10.1002/jpln.200625033

United States Agency International Development [USAID]. (2014). The Competitiveness and Trade Expansion Program, Staple Foods Value Chain Analysis. Country Report, Kenya.

van Asten, P. J. A., Barro, S. E., Wopereis, M. C. S., \& Defoer, T. (2004). Using farmer knowledge to combat low productive spots in rice fields of Sahelian irrigation scheme. Land Degrad. Develop., 15, 383-396. https://doi.org/10.1002/ldr.619

van Mensvoort, M. E., Lantin, R. S., Brinkman, R., \& van Breemen, N. (1985). Toxicities of Wetland Soils. Wetland Soils: Characterization, Classification and Utilization: Proceedings of the 1984 Workshop (pp. 123-138). IRRI, Los Banos, Laguna, Philippines.

Wang, S. A., Angle, J. S., Chaney, R. L., Delorme, T. A., \& Reeves, R. D. (2006). Soil pH effects on uptake of $\mathrm{Cd}$ and $\mathrm{Zn}$ by Thlaspi caerulescens. Plant and Soil, 281, 325-337. https://doi.org/10.1007/s11104005-4642-9

Wei, X., Hao, M., Shao, M., \& Gale, W. J. (2006). Changes in soil properties and the availability of soil micronutrients after 18 years of cropping and fertilization. Soil and Tillage Research, 91, 120-130. https://doi.org/10.1016/j.still.2005.11.009

Yang, M., Shi, L., Xu, F. S., Lu, J. W., \& Wang, Y. H. (2009). Effects of B, Mo, Zn and their interactions on seed yield of rapeseed (Brassica napus L.). Pedosphere, 19(1), 53-59. https://doi.org/10.1016/S1002-0160 (08)60083-1

Ye, H., Shen, C., Huang, Y., Huang, W., Zhang, S., \& Jia, X. (2015). Spatial variability of available soil microelements in an ecological functional zone of Beijing. Environ Monit Assess, 187, 13. https://doi.org/10.1007/s10661-014-4230-7

Yoshida, S. (1981). Fundamentals of Rice Crop Science. International Rice Research Institute, Los Banos, Philippines.

Zayed, B. A., Salem, A. K. M., \& El Sharkawy, H. M. (2011). Effect of different micronutrient treatments on rice (Oriza sativa L.) growth and yield under saline soil conditions. World J. Agric. Sci., 7(2), 179-184.

Zekri, M., \& Obreza, T. A. (2015). Micronutrient deficiencies in citrus: Iron, zinc, and manganese (pp. 1-3) University of Florida Cooperative Extension Service, Institute of Food and Agricultural Sciences, EDIS.

Zeng, F., Ali, S., Zhang, H., Ouyang, Y., Qiu, B., Wu, F., \& Zhang, G. (2011). The influence of pH and organic matter content in paddy soil on heavy metal availability and their uptake by rice plants. Environmental Pollution, 159, 84-9. https://doi.org/10.1016/j.envpol.2010.09.019

Zhao, K., Liu, X., Xua, J., \& Selim, H. M. (2010). Heavy metal contaminations in a soil-rice system: Identification of spatial dependence in relation to soil properties of paddy fields. Journal of Hazardous Materials, 181, 778-787. https://doi.org/10.1016/j.jhazmat.2010.05.081

\section{Copyrights}

Copyright for this article is retained by the author(s), with first publication rights granted to the journal.

This is an open-access article distributed under the terms and conditions of the Creative Commons Attribution license (http://creativecommons.org/licenses/by/4.0/). 